\title{
A PIACRA JUTÁS LEHETÓSÉGEI A FUNKCIONÁLIS ÉLELMISZEREK TERÜLETÉN
}

-

\section{THE MARKET ACCESS AT THE FIELD OF FUNCTIONAL FOODS} \\ HERDON, István ${ }^{1}$ \\ NÁBRÁDI, András ${ }^{2}$

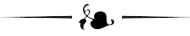 \\ ${ }^{1}$ XANGA Investment and Development Group \\ H-4025 Debrecen, Halköz 2. \\ e-mail: herdon@xanga.hu
}

${ }^{2}$ Debreceni Egyetem, Gazdaságtudományi Kar, Gazdálkodástudományi Intézet

(University of Debrecen, Faculty of Economics and Business

H-4032 Debrecen, Böszörményi út 138 .

e-mail: nabradi@agr.unideb.hu

A funkcionális élelmiszer definíciója „de jure“ nem, „de facto“ létezik, viszont sokan mást értenek alatta. Az egyik legelfogadottabb a következő: Funkcionális élelmiszer olyan természetes vagy feldolgozott élelmiszer, amely ismert biológiailag aktív vegyületeket tartalmaz, amelyet, ha a meghatározott mennyiségben és minőségben adagoljuk, klinikailag bizonyított és dokumentált egészségügyi hatása kimutatható. A definicióból kitűnik, hogy a funkcionális élelmiszerek egy meglehetősen szúk szegmensét fedik le az élelmiszer kategóriáknak.

A Debreceni Egyetem munkatársai a tisztánlátás érdekében az élelmiszerek új kategóriáinak bevezetését javasolták, nevezetesen az „egészségvédő, a különleges táplálkozási célú, a hagyományos és tájjellegú valamint az organikus, vagy bio“ élelmiszer-kategóriákat. Az új csoportosítás mellett kezdeményezték továbbá a „Funkcionális Élelmiszerlánc Terméktanács“ (FÉLT) létrejöttét is, mely szakmaközi szervezet több, különösen a „high tech“ fejlesztésű élelmiszerek csoportjaiban kivánja a termék előállítástól a feldolgozáson értékesítésen és fogyasztáson át ezen perspektivikus élelmiszer kategóriákban múködö felek érdekazonosságát megvalósítani.
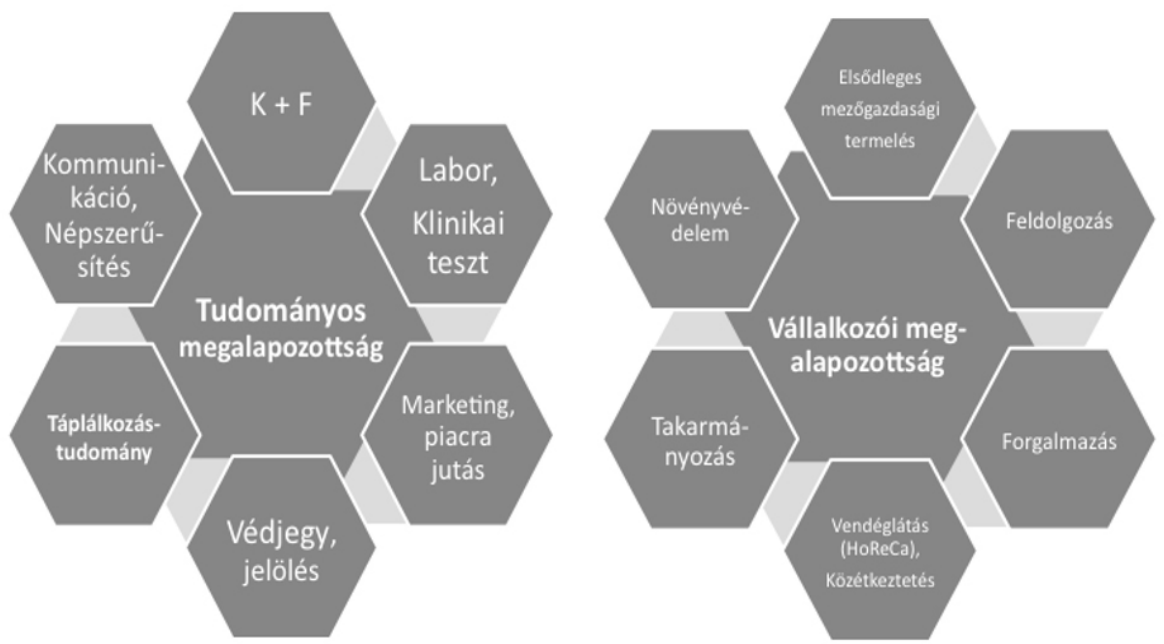

1 ÁBRA

A FÉLT feladat-orientált tervezett munkacsoportjai

FIG. 1 (The Task-oriented Planned Working Parties of FÉLT) 
A számos feladat közül előadásunkban a „piacra jutás“ egyik területét kivánjuk bemutatni, amely egy korábban kezdeményezett együttmúködésen alapszik.

A WX Development Group az Egyesült Arab Emirátusokban az ingatlanfejlesztés, környezetvédelem és kereskedelem területén múködő WDUBAI Group, valamint a Debreceni Regionális és Innovációs Ipari Parkot és a Debreceni Nemzetközi Repülőteret üzemeltető, magyar tulajdonú XANGA cégcsoport közös vállalkozása. A WX Development Group alapításának célja, hogy a magyar és a dubai partner közös fejlesztéseket valósítson meg Magyarországon és az Egyesült Arab Emirátusokban.

A WX Development Group első befektetéseként 2013ban a Debreceni Regionális és Innovációs Ipari Parkban 1 milliárd forint befektetéssel megépült egy vállalkozói inkubátorház, melyben több külföldi vállalat magyarországi leánycége kezdhette meg múködését.

Szintén 2013-ban kezdődtek meg az egyeztetések a Debreceni Egyetem szakembereinek vezetésével az úgynevezett Magyar Funkcionális Élelmiszer Pláza létrehozására vonatkozóan a Dubaiban. A közös projekt megvalósításának legfőbb célkitűzései között szerepel a dubai-magyar kapcsolatok erősítése, a két ország közti kereskedelem fejlesztése, a magyar cégek külföldi piacon való megjelenésének támogatása, valamint a magyar funkcionális élelmiszerek nemzetközi piacra juttatása.

A projekt megvalósításának helyszíne kiemelt jelentőséggel bír, hiszen Dubai a nemzetközi kereskedelem egyik fő központja, Közel-Kelet, Ázsia és Afrika legna- gyobb élelmiszer-elosztó centruma, valamint Halal kereskedelmi bázisa. Az Egyesült Arab Emirátusok számos nemzetközi élelmiszer kiállítást és vásárt rendez évente; a World Expo 2020 rendezési jogát Dubai nyerte el.

A Dubai Szilícium Oázisban megépülő, mintegy 2500 m2 alapterületű élelmiszer pláza az 1000 m2 nagyágú bemutatóterem mellett $500 \mathrm{~m} 2$ iroda és kiszolgáló helyiséget, valamint $1000 \mathrm{~m} 2$ raktárfelületet foglal magában.

A pláza 2014. év végi megnyitását alapos piackutatás előzi meg. Kormányzati adatbázist felhasználva már elkezdődött annak a feltérképezése, hogy milyen élelmiszeripari termékek milyen áron vannak jelen az emirátusokban, és hogy melyek lehetnek azok a magyar árucikkek, amik versenyképesek lehetnek a kinti piacon.

Az élelmiszer pláza szolgáltatásai között szerepel majd a piackutatás, termékek regisztrációja és piaci bevezetése, csomagolási és címkézési tájékoztatás, valamint különféle logisztikai tevékenységek.

Fontos célkitűzés, hogy a 2020. évi World Expo megrendezéséig az élelmiszer pláza keretében egy hatékonyan múködő rendszer kerüljön kiépítésre, mely megkönnyíti a magyar termékek értékesítését a nemzetközi piacokon.

Az Magyar Funkcionális Élelmiszer Pláza projekt kiemelt jelentőségű, hiszen a Debreceni Egyetem koordinációját, valamint a FÉLT kapcsolatrendszerét felhasználva a magyar vállalkozások együttesen, egymást erősítve, alacsony fajlagos költségek mellett jelenhetnek meg a nemzetközi piacokon.

\section{JEGYZETEK * NOTES}

